\title{
CAMBRIAN AND RELATED ORDOVICIAN BRACHIOPODA- A STUDY OF THEIR INCLOSING SEDIMENTS ${ }^{1}$
}

\author{
BY LANCASTER D. BURLING
}

(Read before the Paleontological Society January 1, 1914)

\section{CONTENTS}

Page

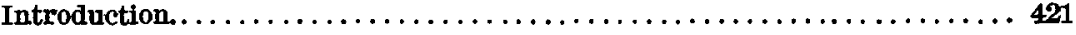

Previous work. .................................. 422

Number of species and varieties occurring in the different types of sedi-

ment............................................4 423

Genera and subgenera identified from but one type of sediment.......427

Lithologic, stratigraphic, and geographic range compared.......... 428

Data as to inclosing sediment classified and compared............429

a. For species occurring more than once in the same section.......429

b. For all species occurring more than once.............. 429

Number of localities and number of species per locality in the different

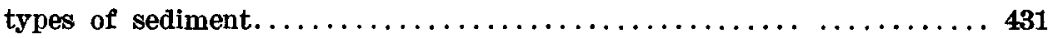

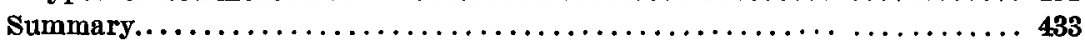

\section{INTRODUCTION}

In his work on the Cambrian and related Ordovician Brachiopoda the writer has had access to approximately 1,350 of the Cambrian fossil localities represented in the collections of the United States National Museum, ${ }^{2}$ from about 72 per cent of which, or 975 , brachiopods have been identified. All of this material and all known references to the occurrence of Cambrian Brachiopoda throughout the world were utilized in this study of the nature of their inclosing sediments, an investigation which was first suggested by Professor Schuchert in a letter to Mr. Walcott, and seemed to be justified by the abundance of the material, its

1 Manuscript recelved by the Secretary of the Geological Soclety April 10, 1914.

Published by permission of the Secretary of the Smlthsonian Institution and the Director of the Geological Survey of Canada.

2 This represents only the number which were available for the work on Monograph 51 of the U. S. Geological Survey on the Cambrian Brachlopoda. The collections of Mr. E. O. Ulrich contain many brachiopods from the Cambrian, as that term is usually defined. 
variety, and the magnitude of its geographic range. The present report is based on the study of 44 genera, 15 subgenera, 477 species, and 59 varieties of Cambrian Brachiopoda, and 3 genera, 1 subgenus, 42 species, and 1 variety of exclusively Ordovician Brachiopoda from 1,460 localities within the national boundaries of 16 countries. The United States is represented by collections from 28 States, Canada by localities in eight of her provinces, and among the continents of the world Africa alone is unrepresented.

The sediments were divided into three classes (limestone, slale, and sandstone) and the following tables were prepared: (1) By genera and subgenera, giving the number of species of each identified from the different sediments; $;^{3}(2)$ by genera and subgenera, listing only those groups which appear to be confined to one type of sediment and giving the number of species of each and the number of localities from which they have been identified; (3) by types of sediment, classifying the mutual relationships between the several horizons of species occurring more than once in the same section; (4) by character of gradation shown between the horizons of all species occurring more than once, and (5) by three arbitrary groups, giving the number of localities and the number of species per locality in each of the three classes of serliment.

\section{Previous Work}

Foremost among previous investigations of a similar character is the exhaustive work of Bigsby." Based on (a) general divisions into (alcareous and non-calcareous sediments and $(b)$. minute discriminations, recognizing 10 or 12 different types of sediment, his results (and not be directly compared with those in this paper, but the following figures may be of interest: "The calcareous or deep-sen sediments are much more" fossiliferous than the arenaceous or shallow bottoms, being as eight to one [823 to 102 (page 264)] in New York and two to one [1,003 to 724 (page 264)] in Wales" (page 260). "Most of the genera of Brachiopoda furnish examples of arenicolous and argillicolous species" (page 262). "Of 254 species of Brachiopoda in New York, of known matrix, only 24 [24 out of 237 (page 264)] are found in non-calcareous sediments: whilst in Wales the distribution is much more general, there being $20 \%$ appearances in the beds just spoken of, against 309 in the limestone rocks" (page 262). Dividing the sediments into groups necessitating a

${ }^{3}$ A preliminary draft of this table was incorporated in Cambrian Brachiopoda. Monogr. U. S. Geol. Survey, vol. li, pt. 1, 1912, by Charles D. Walcott. p. 160.

- Quart. Jour. Geol. Soc. Isondon, vol. 15, 1859, pp. 251-335: Part III.-An inquiry into the sedimentary and other external relations of the Paleozoic fossils of the State of New York. 
discrimination between "calcareous argillaceous shale" and "argillo-calcareous shale," for example, and applying the term divergents to those species which are not constant to single units of this character but deviate into others, he secures the following figures (page 269): Of the 766 known Welch species, 380 , or 49 per cent, are divergents; of the $16 \%$ known Welch Brachiopoda, 114, or 68 per cent, are divergents; of the 841 known New York species, 93, or 11 per cent, are divergent, and of the 225 known New York Brachiopoda, 18, or 8 per cent, are divergent. $\mathrm{He}$ considers the figures for the American area as "an inadequate estimate of the true divergence" (page 267 ). The apparently complete lack of correlation between the different figures given by Bigsby in his exhaustive compilation would seem to indicate a source of error which is probably attributable to the attempt to carry to so fine a degree of minuteness statements by many different authors as to the nature of the inclosing sediment. Furthermore, determinations based on statements as to the lithologic character of the formation from which a species has been identified have not proven to be dependable, since a shale series may contain thin interbedded limestones filled with their own peculiar fauna.

Number of Species and Varie'ties ocCURRING in the DIFFERENT

TyPes OF SFDIMENT

Table I was compiled from a list ${ }^{5}$ of all the species and varieties of C'ambrian and related Ordovician Brachiopoda described in Monograph 51 of the United States Geological Survey, giving the number of times each has been identified from each of the three classes of sediment-for example, Lingulella ferruginea was recognized in 25 faunules, of which 9 were in limestone, 13 in shale, and 3 in sandstone; Obolus apollinis was recognized in 23 faunules, all of them being in sandstone; etcetera, etcetera. Subtracting from the total number of species and varieties ineluded in this list (579) the species for which we have no data as to the inclosing sediment (24), we obtain 555 species, of which 412 , or 74 per cent, have been identified from but one type of sediment. This number (412) includes 218 species that have been identified from one locality only, a fact which, under the conditions governing the separation into localities, precludes their identification from more than one type of sediment. The elimination of this number causes the percentage of species identified from but one type of sediment to fall to 35 , a figure still sufficiently high, in view of the restrictions under which it was secured, to indicate the pronounced influence of the character of the sea-bottom on the distribution of the brachiopodous species.

\footnotetext{
5 This list covers 25 manuscript pages, and the figures for the individual species do not appear to be important enough to justify its inclusion in this paper.
} 


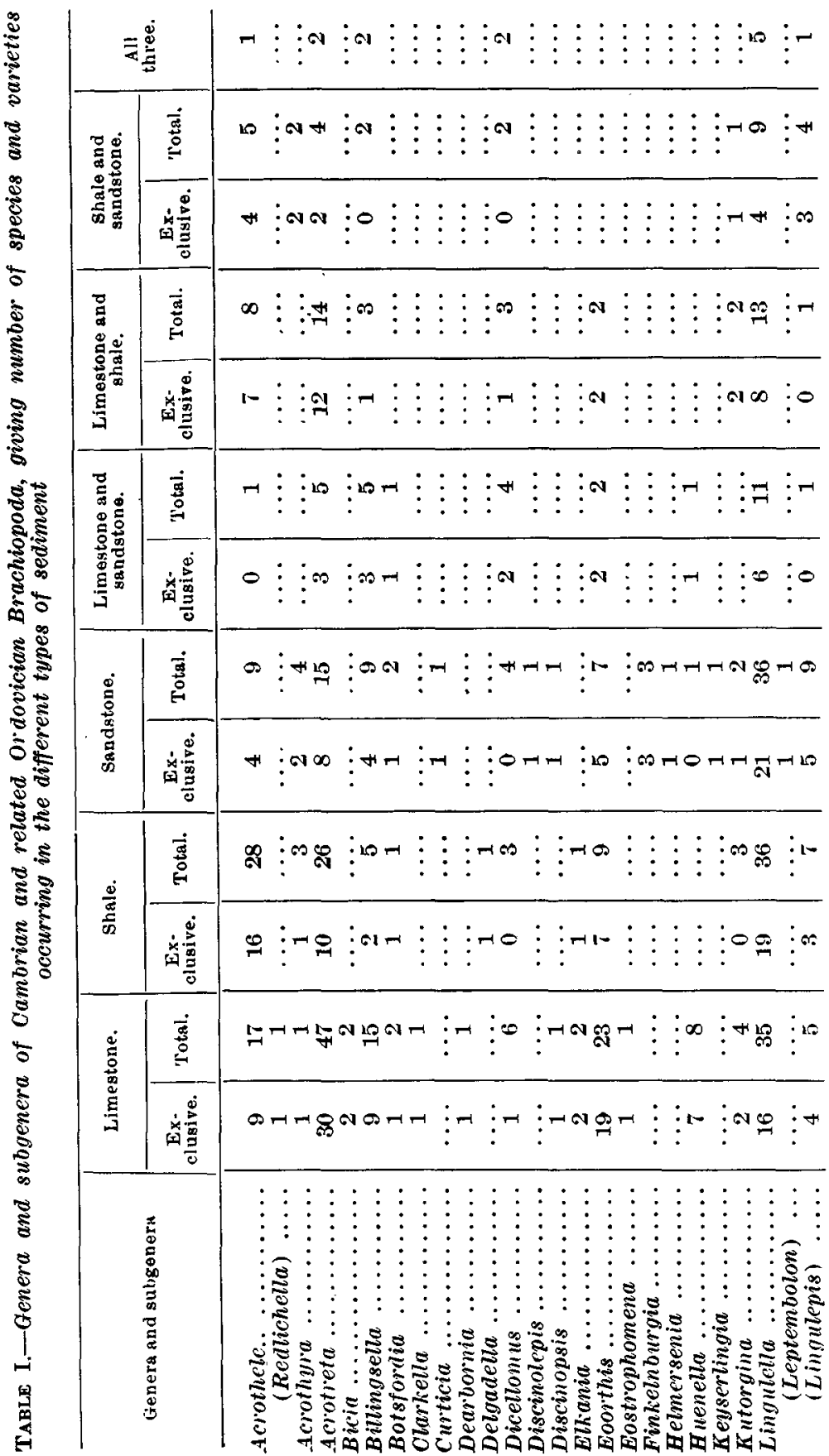




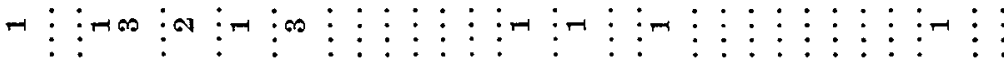

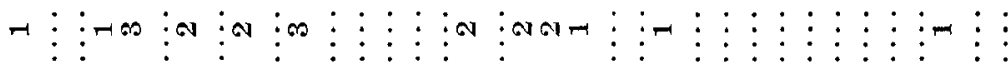

○ : :

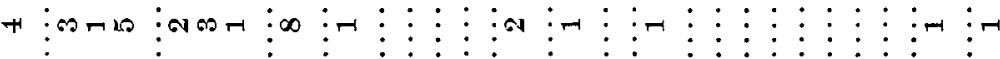

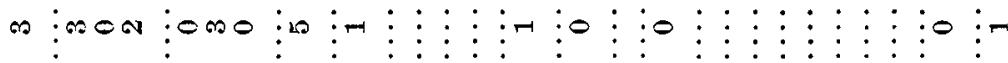

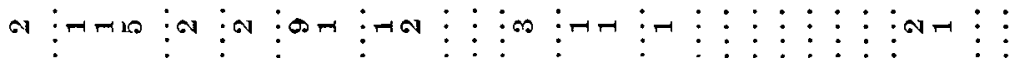

-

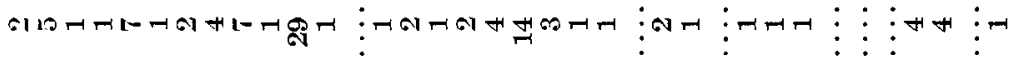

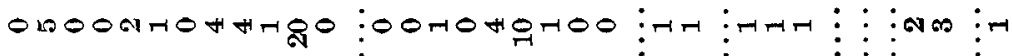

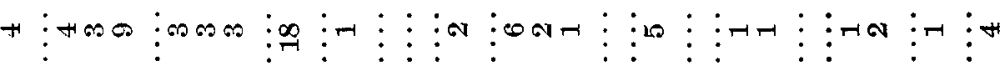

o : r a

1- :

ง $\vdots$ an+o

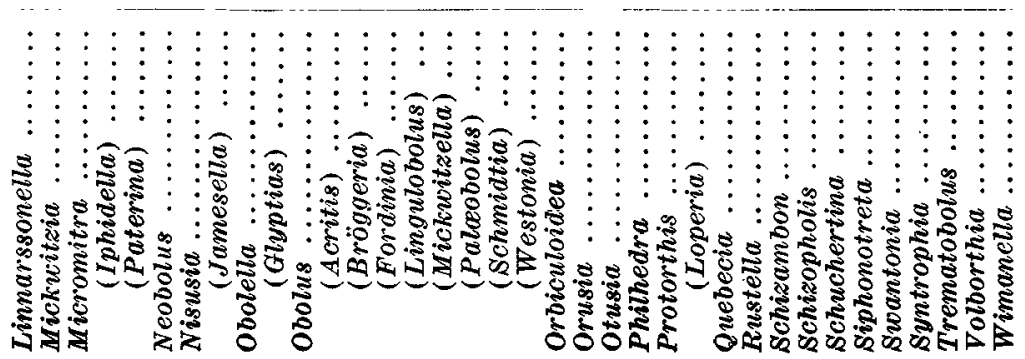




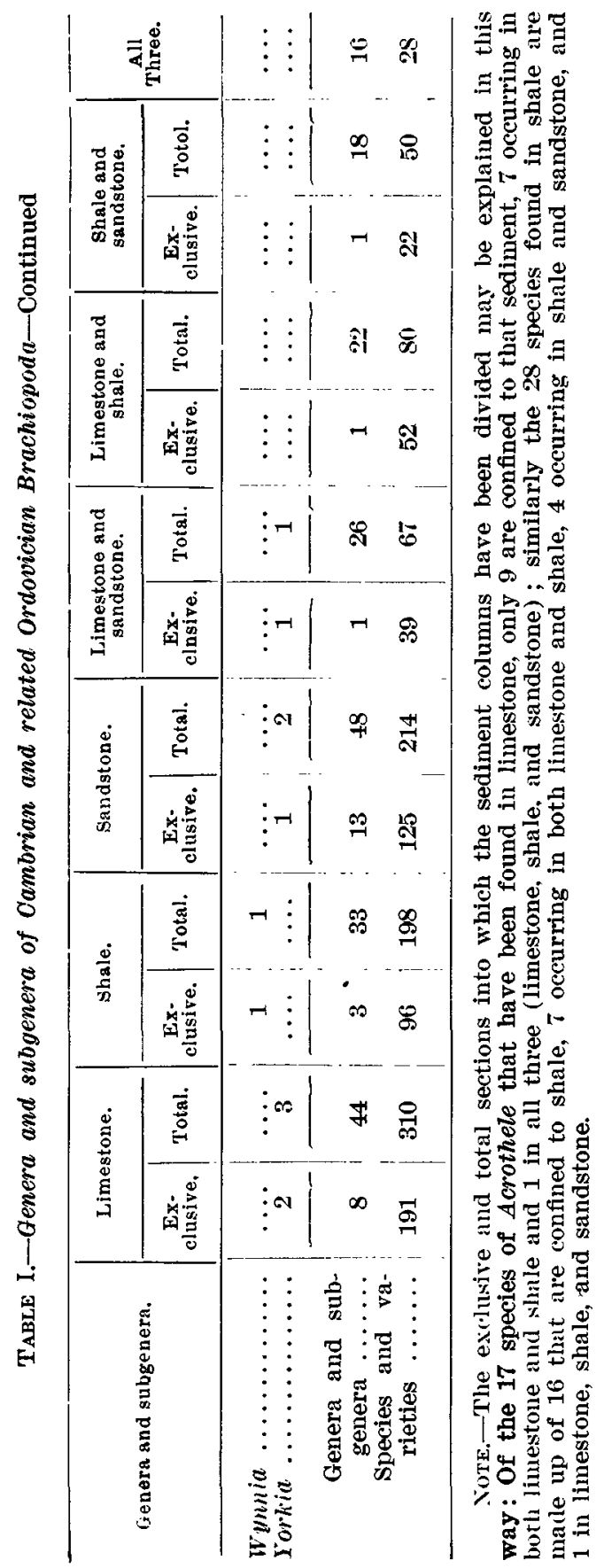


Genera and Subgenera identified from but one Typl of Shimenel

In the following table are listed the twenty-six gencra and subgenera which have been identified from but one type of sediment. In all they form 41 per cent of the total number of these larger groups which have been recognized, but they include within their number twelve genera which are represented only by single species in single faumules. Of the more or less cosmopolitan genera, therefore, only 14 (or 22 per cent) appear to be confined to one type of sediment.

'TABLE II.-Genera and subyenera of Cambrian and related Ordovician Bruchiopoda identified from but one type of sediment, giving numbers of species and localities.

\begin{tabular}{|c|c|c|c|c|c|}
\hline \multirow{2}{*}{$\begin{array}{l}\text { Genera and subgenera, those represented } \\
\text { by single species in single faunules be- } \\
\text { ing placed in this column only, together } \\
\text { with a statement as to the jnclosing } \\
\text { sediment. }\end{array}$} & \multicolumn{3}{|c|}{ Inclosing sedintent. } & \multirow{2}{*}{$\begin{array}{l}\text { Number } \\
\text { of } \\
\text { species } \\
\text { in each } \\
\text { genus. }\end{array}$} & \multirow{2}{*}{ 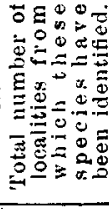 } \\
\hline & $\begin{array}{l}\text { Lime- } \\
\text { stone. }\end{array}$ & Shale. & $\begin{array}{l}\text { Sand- } \\
\text { stone. }\end{array}$ & & \\
\hline \\
\hline 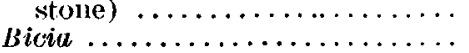 & $\ddot{x}$ & $\begin{array}{l}\ldots \\
\ldots\end{array}$ & $\begin{array}{l}\cdots \\
\cdots\end{array}$ & $\cdots$ & $\cdots$ \\
\hline Clarkella (linestone).......... & $\ldots$ & $\ldots$ & $\cdots$ & - & \\
\hline Curticia (sandstone)........... & $\cdots \cdots$ & $\cdots \cdots$ & $\cdots \cdots$ & $\cdot$ & $\ldots$ \\
\hline Dearbornia (limestone) ......... & $\cdots$ & $\ldots \ldots$ & $\ldots$ & $\cdots \cdots$ & $\cdots$ \\
\hline Delgadella (shale)........... & $\cdots \cdots$ & $\cdots \cdots$ & $\cdots \cdots$ & $\cdots \cdots$ & $\cdots \cdots$ \\
\hline 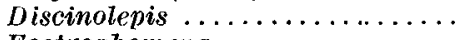 & $\cdots \cdots$ & $\cdots \cdots$ & $x$ & 1 & 2 \\
\hline Eostrophomena $\ldots \ldots \ldots \ldots \ldots$ & $x$ & $\cdots \cdots$ & $\cdots$ & 1 & 2 \\
\hline $\begin{array}{l}\text { Finkelnburgia } \ldots \ldots \ldots \ldots \ldots \ldots \ldots \\
\text { Helmersenia } \ldots \ldots \ldots \ldots \ldots \ldots \ldots \ldots\end{array}$ & $\cdots \cdots$ & $\cdots \cdots$ & $\frac{x}{x}$ & 3 & 21 \\
\hline $\begin{array}{c}\text { Helmersenia } \ldots \ldots \ldots \ldots \ldots \ldots \ldots \ldots \\
\text { Keyserlingia } \ldots \ldots \ldots \ldots \ldots \ldots \ldots \ldots\end{array}$ & $\cdots \cdots$ & $\cdots$ & $\begin{array}{l}x \\
x\end{array}$ & $\begin{array}{l}1 \\
1\end{array}$ & 3 \\
\hline & $\cdots$ & & $\begin{array}{l}x \\
x\end{array}$ & $\begin{array}{l}1 \\
1\end{array}$ & $\ddot{q}$ \\
\hline Mickwitzia $\ldots \ldots \ldots \ldots \ldots \ldots$ & $\cdots$ & $\cdots$ & $x$ & 5 & 18 \\
\hline Neobolus $\ldots \ldots \ldots \ldots \ldots \ldots \ldots$ & $\ldots \ldots$ & $\ldots$ & $x$ & 1 & $\therefore$ \\
\hline Obolella (Glyptias) ........... & $\cdots \cdots$ & $\ldots \ldots$ & $x$ & 1 & 2 \\
\hline obolus (Mickuitzella) ......... & $\ldots$. & $\ldots \ldots$ & $x$ & 1 & 13 \\
\hline Obolus (Schmidtia)............ & $\ldots \ldots$ & $\ldots \ldots$ & $x$ & 4 & 37 \\
\hline Philhedra (limestone) ......... & $\cdots \cdots$ & $\ldots \ldots$ & $\cdots \cdot$ & $\cdots \cdots$ & $\cdots \cdot$ \\
\hline Protorthis (Loperia) (sandstone) & $\cdots \cdots$ & $\cdots \cdots$ & $\cdots \cdots$ & $\cdots$ & $\cdots \cdots$ \\
\hline Quebecia (linestone).......... & $\ldots \ldots$ & $\ldots \ldots$ & $\ldots$. & & $\ldots$. \\
\hline Schizopholis (sandstone)....... & $\ldots$. & $\ldots \ldots$ & $\ldots$ & . & $\ldots$ \\
\hline Schuchortina (limestone)....... & $\ldots$ & $\ldots \ldots$ & $\ldots$. & & \\
\hline Siphonotrcta $\ldots$ & $x$ & $\ldots$ & $\ldots$ & 2 & 23 \\
\hline Sucantonia $\ldots \ldots$ & $\ldots \ldots$ & $x$ & $\cdots \cdots$ & 2 & 2 \\
\hline Volborthia (limestone)......... & $\ldots$ & $\ldots \ldots$ & $\cdots \cdots$ & $\cdots$ & $\cdots \cdots$ \\
\hline Wynnia (shale)............ & $\cdots \cdots$ & $\cdots \cdots$ & $\cdots \cdots$ & . & $\cdots \cdots$ \\
\hline Totals for limestone. . & 3 & $\cdots$ & $\cdots \cdots$ & 5 & 31 \\
\hline Totals for shale. ........ & $\cdots \cdots$ & 1 & $\cdots \cdots$ & 2 & 2 \\
\hline Totals for sandstone...... & $\cdots \cdots$ & $\cdots$ & 10 & 19 & 108 \\
\hline
\end{tabular}

6In Monograph 51 of the r. S. Teological Survey on the Cambrian Brachiopoda it poorly preserved Lower Cambrian shale species is very tentatively referred to this typi. cally Ordovician genus under the name of siphonotreta, dubia, but it is from a single faunule and is described by Mr. Walcott as probably representative of a new type. 
Of the twelve genera and subgenera represented by single species in single faunules, 7 occur in limestone, 2 in shale, and 3 in sandstone. For the fourteen more widely distributed genera the following cliseussion of the results embodied in the table may be of interest: One genus is con1fined to shale, but the two species of which it is composed are confined to single faunules. The apparently isolated examples of Bicia and Eostrophomena from limestone might likewise be dismissed if it were not for the inclusion of Siphonotreta, ${ }^{7}$ a genus which is typically represented by two species from 23 localities. Three genera are thus not only confined to limestone, but are represented, in the case of Bicia and Siphonotreta at least, by a sufficient number of localities to render noteworthy their affinity for calcareous sediments. The genera and subgenera which appear to be confined to sandstone have been recorded largely from single geologic provinces; but these regions have been extensively studied and the figures are large enough to be convincing, if indeed they do not prove a marked preference on the part of several of these generic groups for an arenaceous habitat. Thus ten genera and subgenera, represented in the collections at our disposal by 19 species from 108 localities, appear to be confined to sandstone.

\section{LITHOLOGIC, STRATIGRAPHIC, AND GEOGRAPHIC RANGE COMPARED}

Species common to different sediments are shown on analysis to exhibit a more or less similar latitude in their stratigraphic range; to be exact, 44 per cent of the species occurring in more than one type of sediment (141) have been identified from more than one of the three main divisions (Lower, Middle, and Upper) of the Cambrian.

By a similar analysis it can be shown that there is a still closer relationship between lithologic and geographic range. Thus of the 141 species common to different sediments, 89 (or 63 per cent) have been collected from more than one State, province, or country, the number of such units ranging from 2 to 18 , with an average of over 4 ; and of the 89 species just mentioned, 49 (or 55 per cent) appear to be common not only to four or more of these artificial units, but also to separable geologic provinces.

${ }^{7}$ See the footnote to Siphonotreta on the preceding page. 


\section{Data as to inclosing Sediment classified and COMPáked}

A. FOR SPECIES OCCURRING MORE THAN ONCE IN THE SAME SECTION

TABLE III.-Table classifying the sediment data for species occurring more than once in the same section

\begin{tabular}{|c|c|c|c|}
\hline $\begin{array}{l}\text { Type of gradation in passing from } \\
\text { older to younger strata. }\end{array}$ & $\begin{array}{c}\text { Number of } \\
\text { species showing } \\
\text { gradation. }\end{array}$ & $\begin{array}{l}\text { Number of } \\
\text { species occur- } \\
\text { ring in both } \\
\text { facies of inter- } \\
\text { bedued series. }\end{array}$ & $\begin{array}{l}\text { Number of } \\
\text { species occur- } \\
\text { ring at ap- } \\
\text { proximately } \\
\text { same horizon, } \\
\text { records in- } \\
\text { definite. }\end{array}$ \\
\hline $\begin{array}{l}\text { Shale to limestone. . . . . . . . . . } \\
\text { Limestone to shale... . . . . . . . . } \\
\text { Limestone to shale to limestone... }\end{array}$ & $\begin{array}{r}12 \\
4 \\
4\end{array}$ & 10 & 7 \\
\hline Sundstome to limestomo.......... & 7 & 2 & 4 \\
\hline $\begin{array}{l}\text { Sundstone to shale... . . . . . . . . } \\
\text { Shale to sandstone... . . . . . . . . } \\
\text { Sandstone to shale to sandstone. . }\end{array}$ & $\begin{array}{l}\mathbf{6} \\
4 \\
2\end{array}$ & 2 & 0 \\
\hline Limestone, shale, and sandstone... & 0 & 0 & 0 \\
\hline
\end{tabular}

Perhaps the most interesting features of the preceding table are (a) the fact that no discovered species of Cambrian Brachiopoda is in any one section common to limestone, shale, and sandstone; $(b)$ the pronounced affinity of single species for both facies of an interbedded series composed of shale and limestone; and $(c)$ the relatively high percentage of species able to accommodate themselves to a vertical change from sandstone to limestone and the absence of any species exhibiting the reverse progression.

\section{B. FOR ALL SPECIES OCCURRING MORE THAN ONCE}

TABLE IV.-Table classifying the sedimient data for all species occurring more than once

\begin{tabular}{|c|c|c|c|c|}
\hline $\begin{array}{l}\text { Type of gradation in passing from } \\
\text { older to younger strata. }\end{array}$ & $\begin{array}{l}\text { Number of } \\
\text { species } \\
\text { occurring } \\
\text { in the same } \\
\text { section. }\end{array}$ & $\begin{array}{l}\text { Number of } \\
\text { species } \\
\text { occurring } \\
\text { in adja- } \\
\text { cent } \\
\text { sections. }\end{array}$ & $\begin{array}{l}\text { Number of } \\
\text { species } \\
\text { occurring } \\
\text { in the same } \\
\text { province. }\end{array}$ & $\begin{array}{l}\text { Number of } \\
\text { species } \\
\text { occurring } \\
\text { in different } \\
\text { provinces. }\end{array}$ \\
\hline $\begin{array}{l}\text { Coarse to fine........... } \\
\text { Fine to coarse } \ldots \ldots \ldots \ldots \ldots \ldots\end{array}$ & $\begin{array}{l}31^{8} \\
14^{8}\end{array}$ & $\begin{array}{r}15 \\
4\end{array}$ & $\begin{array}{r}10 \\
2\end{array}$ & $\begin{array}{l}5 \\
1\end{array}$ \\
\hline $\begin{array}{l}\text { Total showing gradation } \\
\text { Total actually or apparently } \\
\text { occurring in different sedi- } \\
\text { ments of the same age.... }\end{array}$ & 45 & 19 & 12 & 20 \\
\hline
\end{tabular}

8 The four limestone-shale-limestone and the two sandstone-shale-sandstone gradations of Table III are credited to each of these figures: their elimination leaves the ratio of coarse-fine to fine-coarse, as 25 to 8 .

XXX-Bull. Geol. Soc. Am., Vol. 25, 1913 
'T'he apparent synchroneity of (L) the inauguration of major stratigraphic units, (2) the introduction of new and temporarily persistent organic types, (3) the expansion of sea areas, and (4) the successive deposition of finer sediments supports the tabular indication that the majority of the species which appear to have been able to accommodate themselves to changes in the character" of the sea-bottom are the ones ac"rompanying granlations from the more clastic to the less. The figures for the more widely scattered ocentrences (columus 3,4 , and 5) are naturally less signilicant, than these for individual sections (column 2 ), but they appear Io be corroborative, and thus bear evidence of a certain dependability. Wren with a due appreciation of the uncertainties involved, we appear to be justified in assigning to the figures of this table and to those of Table III a more than coincidental origin. 


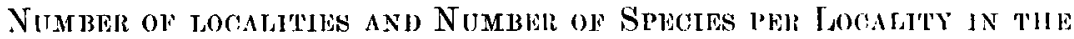

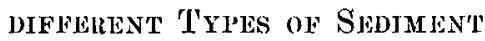

TABLE V.-Groups of Cambrian and rclated Ordovician Brachiopoda giving the number of localitics and the number of species per locality in the different types of sediment.

\begin{tabular}{|c|c|c|c|c|c|c|c|}
\hline \multirow{2}{*}{ Groups. } & \multicolumn{4}{|c|}{ Number of localities. } & \multicolumn{3}{|c|}{$\begin{array}{l}\text { Average number of } \\
\text { species per locality. }\end{array}$} \\
\hline & Total. & Shale. & $\begin{array}{l}\text { Sand- } \\
\text { stone. }\end{array}$ & $\begin{array}{l}\text { Lime- } \\
\text { stone. }\end{array}$ & Shale. & $\begin{array}{l}\text { Sand. } \\
\text { stone. }\end{array}$ & $\begin{array}{l}\text { Lime- } \\
\text { stone. }\end{array}$ \\
\hline 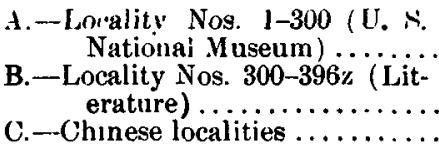 & $\begin{array}{r}703 \\
642 \\
35\end{array}$ & $\begin{array}{r}192 \\
170 \\
12\end{array}$ & $\begin{array}{r}189 \\
241 \\
0\end{array}$ & $\begin{array}{r}322 \\
231 \\
23\end{array}$ & $\begin{array}{l}2.15 \\
1.55 \\
1.75\end{array}$ & $\begin{array}{r}2.77 \\
1.70 \\
0\end{array}$ & $\begin{array}{l}2.81 \\
1.73 \\
1.96\end{array}$ \\
\hline
\end{tabular}

The groups into which this table has been divided require a word of explanation. Group A, numbers 1 to 300 , includes collections that have been made by members of the United States Geological Survey and the United States National Museum at various times and under differing conditions since the organization of the museum. With few exceptions each represents a distinct faunule, definitely numbered, and all of the brachiopods were culled for the work on the Cambrian Brachiopoda. Group B, numbers 300 to $396 \mathrm{z}$, represents miscellaneous collections in the United States National Museum to which locality numbers have never been assigned and occurrences mentioned in the literature. The numbers have been arbitrarily assigned, there is no certainty that each number represents a distinct faunule, and in the case of the localities taken from the literature there is hardly the probability that all of the brachiopods occurring at each of the localities were described. Group C, the collections made by the Carnegie Institution of Washington Expedition to China, is probably the best of the three for the purposes of this study, since all of the collections were made by one man, under more or less similar conditions, during a single field season; yet sandstones are entirely unrepresented. Moreover, the forms from each of the groups (Group B containing the only specific occurrences that have not been checked by actual examination of the specimens themselves) have been studied under more or less uniform conditions by the same. specialists. Among these three groups there appears to be no uniformity of ratio between the number of localities in each of the three classes of sediment and the total number included in the group. For the first two groups 
the percentage of shale localities is 27 , but the non-aceordance of the other percentages would place this as a mere coincidence. Perhaps the most noticeable feature is the uniformity in the figures for each of the types of sediment; in fact the figures were so general that they were believed to indicate little or nothing until the study of the number of species per locality was completed. This number varied from 1 to 15 in both sandstone and limestone and from 1 to 13 in shale, and the averages for the groups betrayed so little evidence of system that the ratio between them was computed. Thus the ratio between the number of speeies per locality in shale and limestone for Group (1) is .89) $\left(\frac{1.75}{1.96}\right)$; for Group B it is $.896\left(\frac{1.55}{1.73}\right)$. The ratio between the number of species per locality in shale and limestone for Group A was $.765\left(\frac{2.15}{2.81}\right)$, a number differing so greatly from the ratios for Groups $\mathrm{B}$ and $\mathrm{C}$ that the ratios between the number of species per locality in sandstone and limestone was computecl for Groups A and B, giving $.985\left(\frac{2.77}{2.81}\right)$ in the former and .982 ( $\left(\frac{1.70}{1.73}\right)$ in the latter case. For Group $\mathrm{C}$ this computation was of course impossible, owing to the absence of collections from sandstone. In view of the multiplicity of the problems involved and the entire lack of interrelation between the groups into which the localities were divided, the ratios afford fairly clear evidence of the accuracy of all of the figures except 2.15 , the number of species per locality in shale for Group A, and would seem to indicate that the number of species per locality is smaller in shale than in sandstone and greatest in limestone.

The accordance of the results is all the more remarkable when we remember that the following factors, if they were not more or less compensatory, might easily have vitiated the results: (1) Errors in the identification of the sediment due to the presence in the collections of gradational types whose classification was of necessity somewhat arbitrary; beds neither predominantly arenaceous or calcareous, for example, which might on second examination be referred differently; (2) errors in the determination of the true nature of the inclosing sediment because of local variations in the matrix immediately surrounding the fossil; and (3) errors in the identification of the species themselves. Most of the leterminations of sediment were made by examination of the hand specimens on which the species are preserved, and in no case have these original results been verified or changed. For this reason the one sandstone representative of the genus Huenella may either be incorretcly assigned to that genus or may occur in a sandstone calcareous enough to justify its transfer to the limestone column. On the other hand, both of these identifications may be correct and the genus may occur in both types of sediment. 
The resulis do not necessarily prove that a species is to be considered as generally confined to one type of sediment; it may have been collected from shale only, for example, when it may also occur in sediments of entirely different character, but of identical age, in which it has not yet been discovered. Neither can the single fact that two beds of unlike lithologic characters bear different faunas be advanced as an indisputable argument against their contemporaneity. Certain it is that modern brachiopods appear to be able to exist at widely differing depths without observable modification in structure, and we know of apparently identical fossil forms which have preserved their individuality through lateral as well as vertical changes in the character of the inclosing sediment. We should be justified, however, in saying that the evidence at hand for the Cambrian and related Ordovician Brachiopoda points largely to a more or less positive influence of the character of the sea-bottom on both the nature and the number of the inhabiting species.

\section{SUMMARY}

A careful study of the known Cambrian and Lower Ordovician brachiopod localities considered in this paper shows $(a)$ that the 47 genera, 16 subgenera, 519 species, and 60 varieties represent 1,460 localities in 16 countries and 5 continents; $(b)$ that from about 72 per cent of the localities represented in the United States National Museum brachiopods have been identified; $(c)$ that, dividing the sediments into three groups (shale, sandstone, and limestone), 41 per cent of the genera and subgenera and 74 per cent of the species and varieties appear to have been identified from but one type of sediment; ${ }^{9}(d)$ that of the 26 genera and subgenera which appear to be confined to one type of sediment only 14 (or 22 per cent of the total number of known genera) have been identified from more than one faunule, but that of this number ten (or 71 per cent) are confined to sandstone; $(e)$ that 44 per cent of the species occurring in more than one type of sediment have been identified from more than one of the three main divisions of the Cambrian; $(f)$ that of the species common to differing types of sediment, 63 per cent have been collected from more than one State or similar artificial unit, and that of this number 55 per cent are also common to separable geologic provinces; ( $g$ ) that the species occurring more than once in the same section largely (45 out of 70) accommodate themselves to vertical changes in the character of their inclosing sediment, though an appreciable number (14)

${ }^{9}$ These figures (41 and 74 ) become reduced to 22 and 35 per cent respectively by the elimination of $(a)$ genera represented by single species in single faunules and $(b)$ species represented by single localities. 
frequent both facies of an interbedded series; $(h)$ that of the 45 species just mentioned the number oceupying positions in the stratigraphic sequence where the gradation upward is from the more clastic to the less is from two to five times that of species showing the reverse progression; and $(i)$ that after dividing the 1,460 localities into three entirely distinct and unrelated groups there are obtained for each of the groups and for each of the types of sediment average figures which bear striking mathematical evidence of the reliability of their indication that while the number of species per locality is remarkably uniform it is smaller in shale than in sandstone and greatest. in limestone. 